\title{
JIŘí ReJZEK
}

\section{PSL. *marbnb A DALŠÍ ODVOZENINY OD KOŘENE *mar-}

CoBISS: 1.01

\begin{abstract}
Psl. * marbnb in druge izpeljave iz korena *mar-
Prispevek se ukvarja s psl. besedami *marbnъ, *mariti, *mara in drugimi izpeljavami iz korena *mar-, katerih etimološka in besedotvorna razmerja so prepletena in jih različni avtorji interpretirajo različno. Na podlagi pomenov posameznih besed se prispevek trudi za kar najbolj verjetno podobo njihovih etimoloških in besedotvornih razmerij.

Ključne besede: etimologija, semantični razvoj, besedotvorna razmerja
\end{abstract}

\section{Proto-Slavic *marbnz and other derivatives from the root *mar-}

This article discusses the Proto-Slavic words *marbnb, *mariti, *mara, and other derivatives from the root *mar- whose etymological and word-formation relations are puzzling and are interpreted differently by various authors. Departing from the meanings of individual words, the article draws the most plausible picture of their etymological and word-formation relations.

Keywords: etymology, semantic development, word-formation relations

Stč. marný se objevuje v mnoha stč. dokladech ve významech 'daremný, nicotný, pomíjivý; chatrný, bídný’ (MSS: 132). V podstatě totožný význam mají i slk. márny, hl., dl., p. marny, br. márny, ukr. a r.d. márnyj i sln.st. máren, přidat je možno i csl. zamarbnъ 'futilis' (srov. ESSJa 17: 219). Na základě těchto výrazů je možno bez problémů rekonstruovat psl. *marbnъ, staré adjektivum odvozené sufixem -bnb.

Problém nastává, pokud máme stanovit výchozí útvar, od něhož je *marbnъ odvozeno. Sufixem -bnъ se tvoří primárně desubstantivní adjektiva (Erhart - Večerka 1981: 98), ale najdeme i řadu př́ipadů tvoření od sloves, pro něž můžeme předpokládat již psl. stáŕí (srov. stč. varný, berný, milovný apod.). Jako fundující slovo našeho adjektiva tedy připadá v úvahu psl. *mara 'přízrak, (zlý) duch', doložené v b., zsl. (kromě č.) a vsl., s výrazně menší pravděpodobností pak psl. *marb 'suchá mlha, sluneční žár' doložené jen v r.d. Mezi slovesy se nabízí psl. *mariti (se), které se ovšem ve slovanských jazycích objevuje v řadě různých významů 'hřát (se)' (b., podobné významy 'žhnout, pálit (o slunci)' jsou i v r. dialektech), 'kazit, ničit, neužitečně trávit' (č., slk.), 'vidět ve snách, snít, toužit' (slk., p., ukr.). ESSJa (17: 212) slučuje všechny tyto významy do jednoho slovesa, které vyvo-

Tato studie vznikla za podpory projektu Univerzity Karlovy Progres č. 4, Jazyk v proměnách času, místa, kultury. 
zuje od výše uvedeného *mara, *marb. Vedle toho ESSJa (17: 212), rekonstruuje i psl. *marěti, jež údajně pokračuje v č. mářěti 'mdlít, ochabovat'1 a hl.st. marjeś 'vadnout od slunečního žáru', přidat je možno spíš psl. *mar'ati na základě sln. marjati 'zabíjet', csl. umarjati (Snoj in: Bezlaj II: 168). Blízko k těmto významům má br.d. máryc' 'mořit, trápit'. Jako homonymní se odděluje *mariti II, *marati (ESSJa 17: 214), které má významy 'starat se, dbát, projevovat náklonnost' a je doloženo pouze v jsl. (od toho i s./ch. máran, sln. máren 'pilný, přičinlivý', které je tak homonymní s výše uvedeným máren).

Vidíme tedy značnou škálu významů, což komplikuje etymologický výklad. Významově se jako fundující slovo psl. *marbnъ zdá být nejblíže sloveso *mariti právě v těch významech, které jsou doloženy ve stč. Problémem je, že stč. mařiti je doloženo poměrně okrajově, 2 zatímco adj. marný je mnohem četnější a navíc ve stejném významu doloženo v celé zsl., ukr. a sln. Navíc na etymologické souvislosti č. mařiti jsou různé názory, jež je rovněž třeba přiblížit:

Zubatý (1946 I/2: 103) spojuje mařiti i marný s psl. *marz, *mara, jež vyvozuje z kořene *ma- 'mámit, klamat', jehož rozšířeními jsou i *mam- a *man-. Podobný výklad zastávají Holub - Kopečný (1952: 217), kteří však uvažují i o sekundárním vlivu slovesa *merti. Machek (1968: 353) počítá se splynutím dvou sloves: mařiti 1 'usmrcovati', které by patřilo k mřiti, faktitivum jako mořiti, jenže s délkou v kořeni, což ukazuje na starobylost tohoto útvaru, a mařiti 2 'kazit (plány), ničit (naděje), utrácet (majetek)', jež by bylo příbuzné se sthn. marrjan 'překážet, bránit, rušit' a angl. mar 'mařit, kazit' (cituje Bezlaj II: 167, odmítá ESSJa 17: 214). Spojení s germ. slovy (navzdory zdánlivé shodě formy i významu) je neprrijatelné - vzhledem k příbuznosti gót. marzjan 'překážet, rušit' musí být výchozí germ. podobou *mers- (srov. LIV 441). Pro slk. marit’ přijímá Králik (2015: 347) jako možnost první část Machkova výkladu (kauzativum k merti), druhou možností je podle něj odvození od marit' sa 'jevit se v neurčitých obrysech'; sémantický vývoj by pak byl 'neskutečný (př́zrak)' $\rightarrow$ ‘činit neskutečným, znemožňovat existenci'. Polské slovníky celkem bez rozpaků spojují mara 'přízrak, vidina, duch, sen', marzyć 'snít, toužit' i marny. Brückner (1927: 322) přijímá Zubatého myšlenku o rozšíření původního *ma-, Bańkowski (2000: 140) a Boryś (2005: 314) vycházejí z ie. *mōr-, mər-, resp. *mer- 'blýskat se, mihotat se', liší se však v otázce fundace adj. marny - Boryś je vyvozuje od *mariti 'způsobovat, že se něco ukazuje, vyjevuje', Bańkowski od *mara s předpokládaným sémantickým vývojem 'nereálný, rychle pomíjející' $\rightarrow$ 'daremný'. Ukr. máryty je podle Bańkowského z p., ale č. mařiti sem nepatří. Bezlaj (II: 167) spojuje s č. mařit sln. marjati 'mořit', csl. umarjati 'zabíjet', s./ch. -márati 'usmrcovati', odmárati 'odpočívat', vše od *mer-; adj. marný sem však podle něj nepatří.

1 Toto slovo je však nejspíš Husův neologismus (srov. Němec 1968: 151), takže psl. rekonstrukce založená pouze na ojedinělém hl. př́íkladě je pochybná.

2 Srov. 4 doklady u Gebauera - Nerod'te... časóv mařiti HusPost. 115b; nemařme náděje zlými skutky HusE. 1, 86; nemarz své mladosti OpMus. 147b. - marzye prázdně vacant Fagif. 46a. 
U psl. slovesa *mariti, ale i dalších odvozených slov můžeme tedy rozeznat celkem čtyři výrazné sémantické okruhy: 1. 'usmrcovat, ničit, utrácet', 2. 'přizrak, vidění; jevit se ve snách, snít, toužit', 3. 'hřát, žhnout, pálit' a 4.'starat se, dbát'. Tyto sémantické okruhy, ač zdánlivě výrazně odlišené, ovšem jeví řadu styčných ploch. Hl. st. marjeś 'vadnout od žáru' spojuje okruhy 1 a 3. R.d. márít' 'řinout se (o parách) nad zemí za teplého počasí v době tání sněhu’ se zdá být na pomezí okruhů 2 a 3. Hl. mara 'bohyně nemoci a smrti' se logicky spojuje s p. mara 'přízrak, (noční) duch, sen' (2), zároveň je lze sotva oddělit od č. morana, mořena, mařena 'bohyně smrti, smrt' a kořene *mer- 'mřít' (1). Slovesa s významem 'starat se, dbát' v jsl. se většinou berou jako homonymní (ESSJa 17: 214; Snoj in: Bezlaj II: 167), ale významy 'chtít, přát si’ (s./ch. máriti, sln. márati) mají blízko k významu 'snít, toužit' v p. marzyć (2), zatímco významy 'starat se, dbát, rmoutit se' jeví styčné body s okruhem (3), srov. č. péče či r. pečalit'sja 'rmoutit se' od kořene *pek-. Navíc Kurkinová přichází s myšlenkou, že jsl. *mariti, *marati je od moriti, spojuje tedy okruhy 1 a 4 - významový vývoj vysvětluje 'umírat' $\rightarrow$ 'silně si prát' $\rightarrow$ 'starat se, usilovat' (Kurkina 1985: 12).

Otázkou tedy je, kolik různých etymologických východisek máme hledat pro slova od ie. kořene *mar-, př́ípadně jak rekonstruovat vývoj významu v prrípadě, že se pokusíme některé sémantické okruhy sloučit do jednoho etymonu.

Zřejmá významová souvislost některých z uvedených slov s kořenem *mer-a možnost vysvětlit *mariti jako zdlouženou variantu kauzativa *moriti (Kurkina 1985: 12 uvádí jako paralelu *tariti - *toriti, *zariti - *zoriti, srov. i Varbot 1984: 31n., kde jsou další podobné případy) nás nutí uvažovat o tomto etymologickém spojení jako výchozím. Psl. *mariti by pak mělo význam 'způsobovat, že něco hyne, pomíjí, slábne'. Tento význam je nejlépe dochován v č. mařit a slk. marit' 'kazit, znemožňovat, ničit, neužitečně trávit', případně i br.d. maryc' 'mořit, trápit'; ještě výrazněji je spojení s *mer- 'mř́ít' patrné u iterativa *mar'ati v sln. marjati 'zabíjet', csl. umarjati 'tv.', s./ch. -márati 'usmrcovati'. Od *mariti 'způsobovat, že něco hyne, pomíjí, slábne’ potom snadno odvodíme i adj. *marbnъ 'nicotný, daremný, pomíjivý, bídný', které zůstalo ze všech slovanských slov na mar- významově nejkompaktnější a pokrývá nejrozsáhlejší slov. areál. P. marzyć 'vidět ve snách, snít, toužit' (i ukr. máryty a slk. marit' sa) může být výsledkem významového posunu 'způsobovat, že něco pomíjí' $\rightarrow$ 'dostat se mimo realitu, být ve snách' (srov. zvratnost slovesa v slk. a č. pominout se 'pomátnout se, zbláznit se'), ale možný je i zánik původního *mariti a jeho sekundární tvoření od *mara 'přízrak, duch, sen'. To lze sotva oddělit od *mora 'noční můra, noční strašidlo', v původních představách 'zlá ženská bytost, jejíž duše za noci obchází a tlačí spící na prsou'?3 Souvislost obou slov se však nepřijímá jednoznačně, např. Derksen

3 K podobným významům podoby mara především v ruských a polských dialektech srov. ESSJa 17: 204-206, pro bulharštinu viz BER 3: 659. Etymologickou totožnost obou slov uznává např. Schuster-Šewc (1978-1989: 885-886). 
(2008: 302) kvůli nepravidelným př́izvukovým poměrům počítá spíš s kontaminací a analogií. Psl. *Mora, které má dobře známé paralely především v germ. jazycích (angl. mare, něm. Mahr), se ovšem často od *merti 'mřít' odděluje, ${ }^{4} \mathrm{i}$ když paralela *moriti - *mariti a *mora - *mara vypadá nadějně. Pokud skutečně existovaly dva ie. kořeny lišící se pouze laryngálou s podobnými významy 'mřít' a 'tlačit, svírat', můžeme u slova *mara opět uvažovat o jejich kontaminaci, spíše bychom se však přikláněli k vyvození všech uvedených slov od *mer- 'mřít'. Málo pravděpodobný se nám pak jeví výše uvedený Zubatého návrh odvození od *ma- s předpokládaným významem 'klamat' i výklad polských slovníků z *mer-, *mōr- 'blýskat se, mihotat se' (které LIV nezná); už vzhledem k tomu, že nejstarší csl. a str. doklady s významy 'extáze, ztráta vědomí, zatemnění rozumu, mrákoty' (ESSJa 17: 204-205) ukazují na souvislost se stavem vědomí, jeho slabostí či nedostatečností.

V r. dialektech se sloveso *mariti objevuje v mnoha specifických významech souvisejících s atmosférickými jevy, nejčastěji 'pálit, být parno, dusno (před bouřkou)', ale i 'unavovat, oslabovat, přivádět k spánku' (ESSJa 17: 213). Pravděpodobně jde o specifikaci původního významu *mariti 'způsobovat, že něco hyne, slábne’ na 'zpo̊sobovat, že něco slábne (dusí se) žárem’ (tento význam najdeme i v hl.st. marjeś 'vadnout žárem'). Méně pravděpodobné je zpětné odvození od *mara s motivací 'př́zrak, vzdušný přelud, mrak' $\rightarrow$ 'být parno, dusno'. R.d. mar 'suchá mlha, mračný vzduch, sluneční žár, dřímota' považujeme vzhledem k omezenému výskytu a specifickým významům za deverbativum od r.d. márit', márit'; psl. stáří je tu problematické. V b. pak u slovesa *mariti došlo k zobecnění významu na 'hřát', v jsl. oblasti srov. ještě s./ch. omariti 'zahřát' (Varbot 1984: 23) a odvozené òmar(in)a 'parno, dusno'.

Zřejmě přes význam 'hřát' bychom pak vysvětlili posun k významu 'starat se, dbát, rmoutit se, chtít' v jsl. jazycích ('hřát, pálit' $\rightarrow$ 'rmoutit se, starat se' $\rightarrow$ 'projevovat náklonnost, chtít, přát si'), srov. podobnou motivaci u psl. *peča, *pečovati. Dáváme přednost tomuto výkladu před výše zmíněným návrhem Kurkinové, protože více zohledňuje původní kauzativní charakter psl. *mariti. Nelze zavrhnout ani tradiční výklad od ie. *(s)mer- 'pamatovat si, myslet, starat se' (Pokorny 1959-1969: 969; ESSJa 17: 215; Skok II: 375). Zde je ovšem třeba podotknout, že LIV (517) nově u tohoto kořene rekonstruuje pouze význam 'myslet na, pamatovat si’ a zařazení slovanského materiálu považuje za pochybné. Navíc je vždy méně věrohodné, pokud je ie. kořen doložen pouze na části slovanského území.

Domníváme se tedy, že všechny zde diskutované významy a formy lze vyvodit od psl. *mariti 'způsobovat, že něco hyne, slábne', zdloužené varianty kořeny má Pokorny 745 i LIV 395-396 (v podobě *mer- 'mřít' a *merh $2^{-}$'tlačit, svírat'). O původní etymologické totožnosti obou kořenů uvažuje Snoj 2003: 414, deklaruje ji BER 4: 237 a ie. *mor-ah $\mathrm{s}^{*}$ *mer-'mřít' spojuje i NIL 489, byt' s pochybnostmi. Derksen (2008: 324) považuje *mora za nejasné a Pokorného spojení s mer- 'tlačit' za nepřsvědčivé. 
kauzativa *moriti od kořene *mer- 'mřít'. Odtud vyložíme i dubletu *mara *mora i další významové posuny slovesa. Původní význam se nejlépe udržel $\mathrm{v}$ č. a slk., ale i v některých $\mathrm{r}$. dialektech a iterativním sln. marjati. Pestrost významových posunů snad lze vysvětlit tím, že slovo *mariti na většině slovanského území etymologicky vykolejilo a jeho souvislost $\mathrm{s}$ kořenem *merpřestala být pocit'ována, snad tu mohlo hrát roli i tabu. Z obecného hlediska se domníváme, že v řadě př́ípadů, kdy se kořeny slovanských slov jeví jako homonymní a přitom nemají jasné etymologie, se ukazuje vhodnější a realističtější je vykládat z rozpadlé polysémie (k tomu srov. i Rejzek 2015).

\section{ZIRATKY}

$\begin{array}{llll}\text { angl. } & \text { anglický } & \text { psl. } & \text { praslovanský } \\ \text { b. } & \text { bulharský } & \text { r. } & \text { ruský } \\ \text { br. } & \text { běloruský } & \text { s./ch. } & \text { srbský/chorvatský } \\ \text { csl. } & \text { církevněslovanský } & \text { slk. } & \text { slovenský } \\ \text { č. } & \text { český } & \mathbf{s l n} . & \text { slovinský } \\ \text { d. } & \text { dialektní } & \text { st. } & \text { starší } \\ \text { dl. } & \text { dolnolužický } & \text { stč. } & \text { staročeský } \\ \text { germ. } & \text { germánský } & \mathbf{s t h n} . & \text { starohornoněmecký } \\ \text { hl. } & \text { hornolužický } & \mathbf{s t r} . & \text { staroruský } \\ \text { ie. } & \text { indoevropský } & \mathbf{t v .} & \text { téhož významu } \\ \text { jsl. } & \text { jihoslovanský } & \text { ukr. } & \text { ukrajinský } \\ \text { něm. německý } & \text { zsl. } & \text { západoslovanský } \\ \text { p. } & \text { polský } & & \end{array}$

\section{LITERATURA}

Bańkowski 2000 = Andrej Bańkowski, Etymologiczny stownik języka polskiego, Warszawa: Wydawnictwo Naukowe PAN, 2000.

BER = Bălgarski etimologičen rečnik $\mathrm{I}-$, Sofia: Akademično izdatelstvo, 1971-.

Bezlaj I-IV = Franc Bezlaj, Etimološki slovar slovenskega jezika I-IV, Ljubljana: Slovenska akademija znanosti in umetnosti, 1977-2005.

Boryś 2005 = Wiesław Boryś, Stownik etymologiczny języka polskiego, Kraków: Wydawnictwo Literackie, 2005.

Brückner 1957 = Stownik etymologiczny języka polskiego, Warszawa: Wiedza Powszechna, 1957.

Derksen 2008 = Rick Derksen, Etymological dictionary of the Slavic inherited lexicon, Leiden: Brill, 2008.

Erhart - Večerka 1981 = Adolf Erhart - Radoslav Večerka, Úvod do etymologie, Praha: SPN, 1981.

ESSJa = Etimologičeskij slovar' slavjanskix jazykov: praslavjanskij leksičeskij fond, Moskva: Nauka, 1973-.

Fasmer I-IV = Maks Fasmer, Etimologičeskij slovar russkogo jazyka I-IV, perevod s nemeckogo i dopolnenija O. N.Trubačeva, Moskva: Progress, 1964-1973.

Gebauer 1903-1916 = Jan Gebauer, Slovník staročeský 1-2, Praha: Česká akademie císaře Františka Josefa, 1903-1916.

Holub - Kopečný 1952 = Josef Holub - František Kopečný, Etymologický slovník jazyka českého, Praha: SPN, 1952. 
Králik 2015 = Lubor Králik, Stručný etymologický slovník slovenčiny, Bratislava: Veda, 2015.

Kurkina 1985 = Ljubov Kurkina, Slavjanskie etimologii, Etimologija 1985, Moskva, 1988, 10-16.

LIV = Helmut Rix et al., Lexikon der indogermanischen Verben, Wiesbaden: Dr. Ludwig Reichert Verlag, 1998.

Machek 1968 = Václav Machek, Etymologický slovník jazyka českého, Praha: Academia, 1968.

MSS = Jaromír Bělič - Adolf Kamiš - Karel Kučera, Malý staročeský slovník, Praha: SPN, 1978.

Němec 1968 = Igor Němec, Vývojové postupy české slovni zásoby, Praha: Academia, 1968.

NIL = Dagmar S. Wodtko - Britta Irslinger - Carolin Schneider, Nomina im Indogermanischen Lexikon, Heidelberg: Universitätverlag Winter, 2008.

Pokorny 1959-1969 = Julius Pokorny, Indogermanisches etymologisches Wörterbuch, Bern: Francke, 1959-1969.

Rejzek 2015 = Jiří Rejzek, On the false homonymy in Slavonic etymology, v: Etymological Research into Old Church Slavonic, ed. I. Janyšková - H. Karlíková, Praha: Nakladatelství Lidové noviny, 2015 (Studia etymologica Brunensia 18), 325-335.

Schuster-Šewc 1978-1989 = Heinz Schuster-Šewc, Historisch-etymologisches Wörterbuch der ober- und niedersorbischen Sprache, Bautzen: Domowina, 1978-1989.

Skok I-IV = Petar Skok, Etimologijski rječnik hrvatskoga ili srpskoga jezika I-IV, Zagreb: Jugoslavenska akademija znanosti i umjetnosti, 1971-1974.

Snoj 2003 = Marko Snoj, Slovenski etimološki slovar, Ljubljana: Modrijan, 22003.

Varbot 1984 = Žana Varbot, Praslavjanskaja morfonologija, slovoobrazovanije i etimologija, Moskva: Nauka, 1984.

Zubatý 1949 = Josef Zubatý, Studie a články I/2, Praha: Česká akademie věd a umění, 1949.

\section{PovzeTEK}

Psl. * marbnъ in druge izpeljave iz korena *mar-

Odraze psl. *marbns 'daremny, nicotny, pomijivy, bidny' nahajamo v podobnih pomenih praktično $\mathrm{v}$ vseh severnoslovanskih jezikih in v slovenščini, le da se na njegovo besedotvorno podstavo ne gleda enotno. V igro prihaja psl. *mara 'prikazen, (zli) duh, sen', ki manjka v češčini in slovenščini in je semantično nekoliko bolj oddaljen, in *mariti $\mathrm{v}$ pomenu 'povzročiti, da se kaj prezre, skazi, onemogoči', ki je ohranjen v češčini in slovaščini, drugod v slovanskem prostoru pa se nahaja v drugih pomenih. Semantična analiza slovanskih besed s korenom *mar- navaja na misel, da je glagol *mariti podaljšana varianta kavzativa *moriti 'moriti, povzročiti, da kaj umre'. Iz tega izvajamo dubleto *mara - *mora 'zli duh, nočna mora, prikazen ipd.' ter nadaljnje premike pomena glagola - 'sanjati, videti v spanju', 'biti soparno, zadušno', iz tega 'greti' in na koncu tudi jsl. 'skrbeti', kar se zvečine ločuje kot homonim. 